\title{
Penyusunan Alat Ukur Partisipasi Birokrat dalam Program Pengurangan Sampah di Kota Bandung
}

\author{
AFIFAH TRI LARASATY1 ${ }^{1}$, JULI SOEMIRAT ${ }^{1}$, SITI AINUN $^{1}$ \\ 1. Jurusan Teknik Lingkungan (Institut Teknologi Nasional Bandung) \\ Email:afifahlarasaty@gmail.com
}

\begin{abstract}
ABSTRAK
Program pengurangan sampah diwujudkan dengan keterlibatan aktif masyarakat maupun pihak pengelola sampah. Dalam mewujudkan keberhasilan suatu program pengurangan sampah di dalam implementasinya juga melibatkan pihak birokrat yang seringkali berperan baik sebagai inisiator, penyelenggara, maupun pengawas program. Terkait hal tersebut, diperlukan adanya sebuah penelitian untuk mengukur tingkat partisipasi birokrat dalam program-program yang diselenggarakan dengan menggunakan teori Arnstein ( $A$ Ladder Of Citizen Participation).Teknik stratified sampling diterapkan untuk menentukan sampel. Penilaian dilakukan dengan skoring dan ranking. Hasil penelitian didapat sebuah alat ukur yang dapat digunakan untuk mengukur tingkat partisipasi birokrat dalam pengelolaan sampah, yaitu berupa daftar pertanyaan, yang terdiri dari 3 bagian, yaitu bagian identitas, umum, dan khusus. Alat ukur utama adalah di bagian khusus yang memiliki 13 pertanyaan yang sudah mencakup pertanyaan terkait tiga tahapan partisipasi, dengan parameter sarana dan prasarana, aturan, kerjasama, pendampingan, dana, serta monitoring dan evaluasi.
\end{abstract}

Kata kunci : Birokrat, Partisipasi, Pengurangan sampah

\begin{abstract}
Waste reduction programs is realized with the active involvement of the community as well as waste management. $A$ waste reduction program in its implementation will also involve bureaucrats who often acts as initiator, organizer, as well as program supervisor. It is therefore important to measure the level of participation of bureaucrats in waste reduction programs using the Arnstein theory (A Ladder Of Citizen Participation). Stratified sampling technique was used to determine the sample size. Assessment was done by scoring and ranking. The result a of this study is a measurement tool that can be used to measure the level of participation of bureaucrats in waste management, namely in the form of a questionnaire, which consists of three parts, namely the identity part, the general, and the special part, i.e., the part on participation. The main measuring tool was in the special section, which has 13 questions related to the three stages of participation, including infrastructure parameters, rules/regulations, teamwork, mentoring, funding, monitoring, and evaluation.
\end{abstract}

Keywords: Bureaucrats, Participation, Waste reduction 


\section{PENDAhULUAN}

Menurut Undang-Undang Nomor 18 tahun 2008 tentang Pengelolaan Sampah, pengelolaan sampah dilakukan dengan penanganan dan pengurangan sampah yang terdiri dari pembatasan timbulan sampah, pendauran ulang sampah dan/atau pemanfaatan kembali sampah. Dalam Peraturan Pemerintah tersebut,pengurangan sampah diwujudkan dengan keterlibatan aktif masyarakat maupun pihak pengelola sampah.

Timbulan sampah yang semakin banyak setiap tahunnya akan menjadi masalah jika tidak terkelola dengan baik. Salah satu pemecahan masalah timbulansampah adalah dengan dibuatnya program-program pengurangan sampahyang bertujuan untuk mengurangi sampah yang akan diangkut ke Tempat Pemrosesan Akhir (TPA). Dalam pelaksanaan suatu program seringkali melibatkan banyak pihak, di antaranya adalah pihak birokrat dan juga masyarakat. Dalam program-program tersebut masyarakat diberikan bekal pengetahuan dan prasarana pendukung sehingga mereka bisa mengelola sendiri sampah di lingkungan tempat tinggalnya. Dalam mewujudkan keberhasilan suatu program pengurangan sampah di dalam implementasinya juga melibatkan pihak birokrat yang seringkali berperan baik sebagai inisiator, penyelenggara, coordinator, maupun pengawas program.

Tingkat keberhasilan sebuah program yang melibatkan masyarakat akan sangat dipengaruhi dari tingkat partisipasi seluruh pihak dalam keseluruhan pelaksanaan program dari awal hingga akhir.Birokrat dapat meningkatkan partisipasi masyarakat dengan membagi kewenangan dan tanggung jawab kepada masyarakat untuk berpartisipasi dalam program dengan menyusun program yang melibatkan masyarakat.Terkait hal tersebut, diperlukan sebuah penelitian untuk mengukur tingkat partisipasi birokrat dalam program-program yang diselenggarakan.

Penelitian ini akan menggunakan teori partisipasi Arnstein. Dalam teori Arnstein tersebut, disebutkan adanya 2 pihak yang terkait dengan partisipasi, yaitu masyarakat dan birokrat. Kewenangan yang diberikan pihak birokrat kepada masyarakat didistribusikan pada tiap anak tangga dari delapan, yang mewakili strategi partisipasi yang berbeda. Keterlibatan masyarakat akan berkembang ketika partisipasi birokratnya sudah membagi kewenangan pada masyarakat dalam suatu program. Alat ukur yang dapat menunjukan tingkatan partisipasi birokrat berdasarkan partisipasi Arnstein. Diharapkan dapat menjadi dasar pengembangan program agar terwujudnya masyarakat yangmandiri dalam pengurangan sampah.

\section{METODOLOGI}

Tahapan yang dilakukan dalam penelitian ini dapat dilihat pada Gambar 1.Pada tahap identifikasi definisi partisipasi dan birokrat dilakukan dengan menggunakan metode studi literatur untuk mempelajari teori-teori yang berhubungan dengan penelitian.Teori yang akan dijelaskan meliputi partisipasi secara umum dan birokrat dari berbagai jurnal.Setelah itu dilakukan pengkelompokan yang memiliki kesamaan dalam penjelasan dari setiap jurnal agar memudahkan peneliti merangkum kata kunci dari masing-masing jurnal.

Tahapan selanjutnya adalah mengidentifikasi birokrat yang berperan dalam program-program pengurangan sampah berdasarkan tugas pokok dan fungsi setiap birokrat.Pengumpulan informasi dilakukan melalui wawancara, serta melalui website dan media sosial. Selain itu, pada tahap ini juga dilakukan pengumpulan informasi terkait program-program yang sudah 
ada di Kota Bandung dalam pengurangan sampah. Dari hasil tersebut dilakukan pengkajian terhadap program yang akan dianalisis.

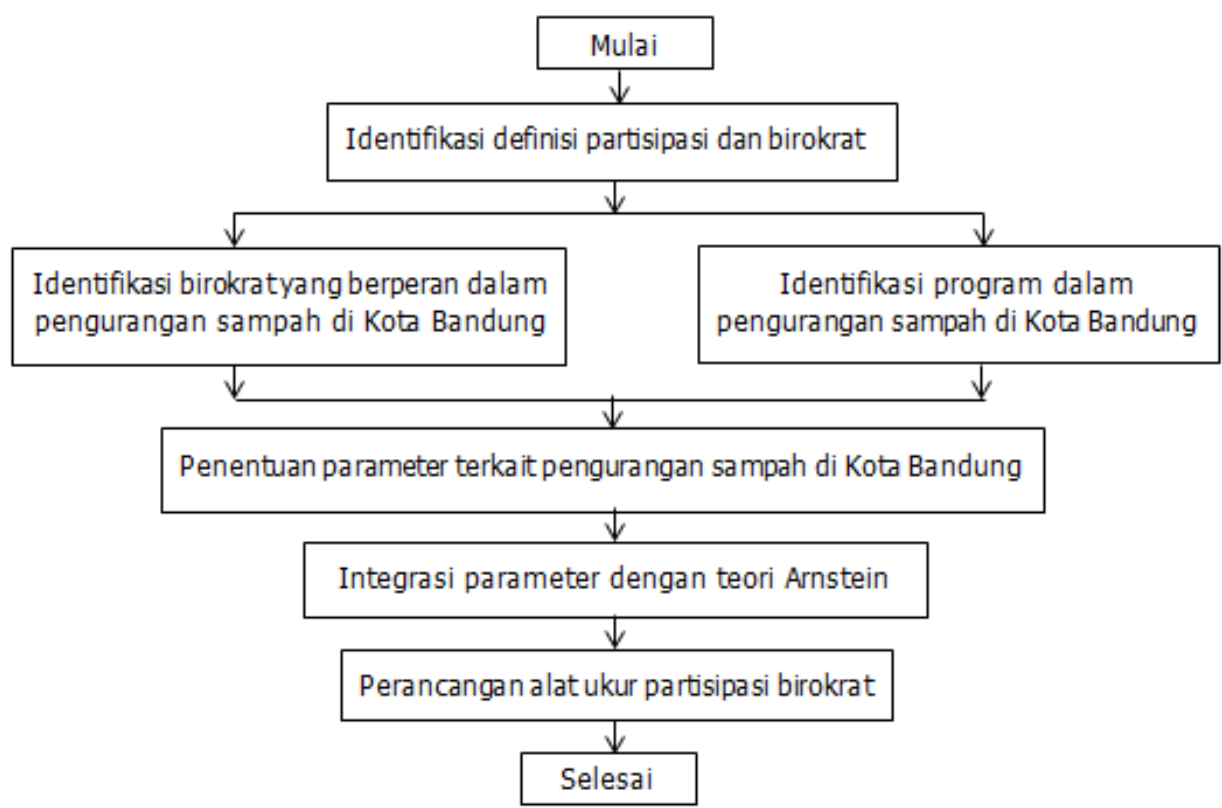

Gambar 1. Penyusunan Alat Ukur Partisipasi Birokrat

Pengkajian tersebut merupakan pemilihan program yang ditentukan berdasarkan kriteria, setelah itu dilihat program yang memenuhi kriteria tersebut.Pengumpulan informasi sama seperti tahapan sebelumnya.Sama halnya dengan tahapan sebelumnya, identifikasi birokrat dilakukan dengan wawancara, website, dan media sosial.

Karena teori tingkatan partisipasi Arnstein dibedakan atas dasar inisiatif pihak masyarakat maupun birokrat, maka dalam penyusunan parameter untuk mengukur partisipasi birokrat dipilih 3 program yang memiliki kriteria. Selain itu juga, mengacu pada peranan, tugas dan wewenang setiap birokrat dalam suatu program agar dapat mengetahui kunci parameter yang akan dijadikan pertanyaan pada wawancara. Setelah itu parameter digabungkan dengan tingkatan tanggapartisipasi Arnstein yang sebelumnya dari sudut pandang partisipasi masyarakat menjadi ke arah partisipasi birokrat. Maka akan didapat pengertian setiap anak tangga dan dikelompokan dalam 3 kelompok besar partisipasi Arnstein yang kemudian akan dijadikan kunci jawaban partisipasi Arnstein untuk menganalisis tingkat partisipasi birokrat terkait pengurangan sampah di Kota Bandung.

Data primer didapat dengan wawancara menggunakan daftar pertanyaan yang mampu memberikan gambaran atau informasi yang menjawab penelitian ini. Tahapan pertama yang dibuat adalah perancangan daftar pertanyaan. Adapun langkah-langkah perancangan daftar pertanyaan yang dibuat untuk mengukur tingkat partisipasi birokrat dalam pengurangan sampah di Kota Bandung adalah sebagai berikut : (1) menentukan tujuan, yakni mengukur partisipasi birokrat dalam pengurangan sampah di Kota Bandung. (2) mengidentifikasi partisipasi dan birokrat (3)mengidentifikasi program pengurangan sampah yang ada di Kota Bandung (4) mengidentifikasi birokrat yang berperan (5) penyusunan parameter (6) merancang pertanyaan yang merupakan fokus utama dalam penelitian ini. (7) wawancara kepada responden. (8) analisis hasil pengukuran.

Pengambilan sampel menggunakan stratified sampling, yakni memperhatikan strata tertentu (sub populasi) terkait program pengurangan sampah (Soleh, 2005). Tahap selanjutnya adalah 
perancangan penilaian menggunakan skoring danranking yaitu data mentah yang kualitatif menjadi semi kuantitatif. Terdapat tiga kunci jawaban dalam daftar pertanyaan untuk bagian III (khusus) yaitu tingkat citizen power yang bernilai 3, tingkat tokenism yang bernilai 2 , tingkat nonparticipation yang bernilai 1 .

\section{ISI}

\subsection{Identifikasi Definisi Partisipasi dan Birokrat - Partisipasi}

Menurut Kamus Besar Bahasa Indonesia (KBBI) partisipasi adalah perihal turut berperan serta dalam suatu kegiatan, keikutsertaan, dan peran serta. Selain itu ada beberapa definisi tentang partisipasi menurut beberapa dapat dilihat pada Tabel 1.

\section{Tabel 1 Definisi Partisipasi Secara Umum}

\begin{tabular}{|c|c|}
\hline Sumber & Pengertian \\
\hline $\begin{array}{ll}\text { Sundariningrum } & \text { dalam } \\
\text { Sugiyah (2001: 38) } & \end{array}$ & $\begin{array}{l}\text { - Partisipasi Langsung } \\
\text { Partisipasi yang terjadi apabila individu atau suatu kelompok menampilkan } \\
\text { kegiatan tertentu dalam proses partisipasi. Partisipasi ini terjadi apabila setiap } \\
\text { orang dapat mengajukan pandangan, membahas pokok permasalahan, } \\
\text { mengajukan keberatan terhadap keinginan orang lain atau terhadap ucapannya. } \\
\text { - Partisipasi tidak langsung } \\
\text { Partisipasi yang terjadi apabila individu atau suatu kelompokmelimpahkan hak } \\
\text { partisipasinya kepada orang lain }\end{array}$ \\
\hline $\begin{array}{l}\text { I Nyoman Sumaryadi, } \\
(2010: 46)\end{array}$ & $\begin{array}{l}\text { Partisipasi berarti peran serta seseorang atau kelompok masyarakat dalam } \\
\text { proses pembangunan baik dalam bentuk pernyataan maupun dalam bentuk } \\
\text { kegiatan dengan memberi masukan pikiran, tenaga, waktu, keahlian, modal dan } \\
\text { atau materi, serta ikut memanfaatkan dan menikmati hasil-hasil pembangunan }\end{array}$ \\
\hline $\begin{array}{l}\text { Fasli Djalal dan Dedi } \\
\text { Supriadi (2001: } 201-202)\end{array}$ & $\begin{array}{l}\text { Partisipasi dapat juga berarti bahwa pembuat keputusan menyarankan } \\
\text { kelompok atau masyarakat ikut terlibat dalam bentuk penyampaian saran dan } \\
\text { pendapat, barang, keterampilan, bahan dan jasa. }\end{array}$ \\
\hline
\end{tabular}

Sumber : Hasil Analisis, 2017

\section{- Birokrat}

Menurut Kamus Besar Bahasa Indonesia (KBBI) birokrat adalah pegawai yang bertindak secara birokratis atau seorang yang menjadi bagian dari birokrasi. Menurut Sedarmayanti (2009:67) birokrasi adalah struktur organisasi yang pejabatnya diangkat atau ditunjuk, garis tanggung jawab dan kewenangannya diatur oleh peraturan dan pertimbangan setiap keputusan membutuhkan referensi untuk mengetahui kebijakan yang pengesahannya ditentukan oleh pemberi mandat di luar struktur organisasi itu sendiri. Maka birokrat ialah seseorang yang memiliki wewenang dan tanggung jawab dalam suatu kelompok atau organisasi.

\section{- Partisipasi Birokrat}

Berdasarkan penjelasan diatas maka untuk kepentingan penelitian ini partisipasi birokrat adalah pihak-pihak yang memiliki kesadaran untuk ikut terlibat dan mempunyai wewenang dan tanggung jawab dalam kegiatan pemerintahan serta pelayanan masyarakat.

\subsection{Identifikasi Birokrat danProgram Dalam Pengelolaan Sampah Di Kota Bandung} Berdasarkan hasil pengumpulan data studi literatur adapun dua jenis birokrat yang berperan dalam pengelolaan sampah di Kota Bandung diidentifikasi sebagai berikut :

1) Birokrat Pemerintah 
Birokrat pemerintah yang terlibat dalam pengelolaan sampah Kota Bandung, yakni Dinas Lingkungan Hidup dan Kebersihan (DLHK) dan Perusahaan Daerah Kebersihan (PDK). Berdasarkan Peraturan Walikota Bandung nomor 1390 tahun 2016 terkait tugas pokok dan fungsi (TUPOKSI) DLHK membantu walikota dalam pelaksanaan urusan pemerintahan yang menjadi kewenangan daerah di bidang lingkungan hidup dan unsur persampahan. TUPOKSI PD Kebersihan yang tercantum dalam Peraturan Walikota nomor 101 tahun 2006 adalah menyelenggarakan pelayanan jasa kebersihan dibidang persampahan, meliputi pengumpulan, pengangkutan, pembuangan, dan pemanfaatan sampah.

\section{2) Birokrat Non Pemerintah}

Birokrat Non pemerintah bekerja di suatu organisasi/lembaga swadaya masyarakat yang mempunyai TUPOKSI melayani masyarakat untuk perubahan sosial dan lingkungan.Menurut Astuti (2012) LSM melakukan berbagai pelayanan, menyampaikan keinginan masyarakat kepada pemerintah, memonitor implementasi program dan meningkatkan partisipasi masyarakat. Pendanaannya didapatkan dari pihak ketiga daninvestor yang membawa inovasi (teknologi, manajemen, pendekatan masyarakat) (Badan Pengelolaan Lingkungan Hidup, 2014). LSM yang terlibat dalam pengelolaan sampah, antara lain: Hijau Lestari (HL), Gerakan Semangat Selalu Ikhlas (GSSI), Lembaga Pengembangan Teknologi Tepat (LPTT), Yayasan Pengembangan Biosains dan Bioteknologi (YPBB), Forum Hijau (FH), Greeneration dll. Selain itu, terdapat tokoh masyarakat yang berada di lingkungan sekitar yang mempunyai wewenang yang sama dengan LSM melayani masyarakat dan juga bertanggung jawab terhadap pelaksanaan program (Nurviyasari, 2012). Untuk tokoh masyarakat adalah tokoh-tokoh yang berperan aktif dalam program tersebut di lingkungan sekitar.

Birokrat pemerintah dan birokrat non pemerintah bisaberbagi dalam hal teknologi, pendanaan, dan kawasan melalui pola kesepakatan. Sedangkan program pengurangan sampah oleh masing-masing birokrat terdapat pada Tabel 2.

Berdasarkan hasil studi litelatur dan wawancara teridentifikasi bahwa ada 2 kelompok birokrat yang memiliki kewenangan dalam berbagai program di atas. Pihak birokrat yang seringkali berperan baik sebagai inisiator, penyelenggara, maupun pengawas program. Program yang diinisiasi oleh ke 2 kelompok birokrat umumnya memiliki tujuan yang sama yaitu mengurangi timbulan sampah di Kota Bandung. Berikut kriteria pemilihan program, yaitu setiap program melibatkan masyarakat, memiliki kesamaan program baik yang dijalankan oleh birokrat pemerintah maupun birokrat non pemerintah. Seperti tampak pada Tabel 2, ada 3 program yang memenuhi kriteria tersebut. Ketiga program tersebut, yaitu : Kawasan bebas sampah, bank sampah, dan biodigester.

- Kawasan Bebas Sampah (KBS)

KBS menerapkan sistem dan teknologi pengolahan sampah perkotaan skala kawasan secara terpadu dengan sasaran untuk melakukan penanganan sampah perkotaan skala kawasan, sehingga dapat mengurangi volume sampah sampai sedikit mungkin, serta terciptanya industri kecil daur ulang yang dikelola oleh masyarakat atau pemerintah daerah setempat(Badan Pengelolaan Lingkungan Hidup, 2014)

\section{- Bank Sampah (BS)}

Menurut Asteria (2016),BS adalah pengumpulan sampah kering dan dipilah serta memiliki manajemen layaknya perbankan tapi yang ditabung bukan uang melainkan sampah. Mempunyai strategi untuk membangun kepedulian masyarakat agar dapat 'berkawan' dengan sampah untuk mendapatkan manfaat ekonomi langsung dari sampah.

- Biodigester (BD) 
BD adalah suatu sistem yang mempercepat pembusukan bahan organik. Darinya terbentuk biogas dan senyawa-senyawa lain yang dihasilkan melalui pembusukan anaerobik.

\subsection{Penentuan Parameter}

Parameter dan kriteria untuk desain pertanyaan diambil dari ketiga program yang memiliki peranan, wewenang dan tanggung jawab dari setiap birokrat, seperti dapat dilihat pada Tabel 3.

Berdasarkan hasil analisis, pada tahapan perencanaan terdapat parameter yang bisa dijadikan 13 pertanyaan. Hasil analisis identifikasi tersebut kemudian diintegrasikan dengan anak tangga Arnstein dengan demikian akan di kelompokan ke dalam tiga tingkat partisipasi, yaitu : non participation, tokenism, citizen power .

Tabel 2 Program Terkait Pengelolaan Sampah

\begin{tabular}{|c|c|c|}
\hline Lembaga & Birokrat & Program Pengelolaan Sampah \\
\hline \multicolumn{3}{|c|}{ Pemerintah } \\
\hline PD. Kebersihan & $\begin{array}{l}\text { - } \text { Direktur Teknik \& Oprasional } \\
\text { - Kepala Bidang Teknik } \\
\text { - Kepala Oprasional Wilayah Bandung Utara } \\
\text { - Kepala Oprasional Wilayah Bandung Selatan } \\
\text { - Kepala Oprasional Wilayah Bandung Barat } \\
\text { - Kepala Oprasional Wilayah Bandung Timur }\end{array}$ & $\begin{array}{l}\text { - } \text { Bank Sampah } \\
\text { - Kawasan Bebas Sampah } \\
\text { - } \text { Biodigester }\end{array}$ \\
\hline $\begin{array}{l}\text { Dinas Lingkungan Hidup dan } \\
\text { Kebersihan (DLHK) }\end{array}$ & $\begin{array}{ll} & \text { Bidang Kebersihan } \\
\text { - } & \text { Seksi Fasilitas Kebersihan } \\
\text { - } & \text { Seksi Fasilsitas Teknik Oprasional } \\
\text { - } & \text { Seksi Peningkatan Kapasitas dan Edukasi } \\
& \text { Kebersihan } \\
\end{array}$ & $\begin{array}{ll} & \text { Kawasan Bebas Sampah } \\
\text { - } & \text { Bank Sampah } \\
\text { - } & \text { Biodigester } \\
\text { - } & \text { Adipura } \\
\text { - } & \text { Adiwiyata } \\
\end{array}$ \\
\hline \multicolumn{3}{|c|}{$\begin{array}{c}\text { Non Pemerintah } \\
\text { Lembaga Swadaya Masyarakat (LSM) }\end{array}$} \\
\hline Hijau Lestari & $\begin{array}{ll}\text { - } & \text { Pengawas } \\
\text { - } & \text { Ketua } \\
\text { - } & \text { Sekertaris } \\
\text { - } & \text { Bendahara } \\
\text { - } & \text { Divisi Pendidiki Pengemban \& Informasi } \\
\text { - } & \text { Divisi Advokasi dan Pendampingan } \\
& \text { Masyarakat }\end{array}$ & $\begin{array}{ll}\text { - } & \text { Bank Sampah } \\
\text { - } & \text { Daur Ulang Sampah }\end{array}$ \\
\hline $\begin{array}{l}\text { Gerakan Semangat Selalu } \\
\text { Indonesia (GSSI) }\end{array}$ & $\begin{array}{ll}\text { - } & \text { Ketua } \\
\text { - } & \text { Sekertaris } \\
\text { - } & \text { Bendahara } \\
\text { - } & \text { Pembina } \\
\text { - } & \text { Pengawas } \\
\text { - } & \text { Fasilitator }\end{array}$ & $\begin{array}{ll}- & \text { Cerita Anak Negeri } \\
\text { - } & \text { Kurangi Pisahkan Manfaatkan } \\
& \text { Sampah (kolaborator KBS) } \\
\text { - } & \text { Pendidikan Sosial Literasi dan } \\
& \text { Lingkungan Hidup }\end{array}$ \\
\hline $\begin{array}{c}\text { Lembaga Penerapan Teknologi } \\
\text { Tepat (LPTT) }\end{array}$ & $\begin{array}{ll}\text { - } & \text { Direktur } \\
\text { - } & \text { Sekertaris } \\
\text { - } & \text { Bendahara } \\
\text { - } & \text { Divisi Keuangan } \\
\text { - } & \text { Divisi Manager Program } \\
\text { - } & \text { Staf Lapangan } \\
\end{array}$ & $\begin{array}{ll} & \text { Bank Sampah } \\
\text { - } & \text { Kawasan Bebas Sampah } \\
\text { - } & \text { Biodigester }\end{array}$ \\
\hline $\begin{array}{l}\text { Yayasan Pengembangan Biosains } \\
\text { dan Bioteknologi (YPBB) }\end{array}$ & $\begin{array}{ll}\text { - } & \text { Ketua } \\
\text { - } & \text { Sekertaris } \\
\text { - } & \text { Bendahara } \\
\text { - } & \text { Divisi Kampanye } \\
\text { - } & \text { Divisi Pengelolaan Sumber Daya } \\
\text { - } & \text { Humas }\end{array}$ & $\begin{array}{ll}\text { - } & \text { Zero Waste } \\
\text { - } & \text { Bank Sampah }\end{array}$ \\
\hline
\end{tabular}


Tabel 3. Identifikasi Parameter

\begin{tabular}{ll}
\hline Parameter & Kriteria \\
\hline Sarana dan prasarana & memberikan kebutuhan alat untuk menjalankan program \\
\hline Pendanaan & mengelola sarana operational \\
\hline mendanai pembangunan infrastruktur persampahan \\
\hline mendanai sistem OM dari suatu program \\
\hline Pendampingan & $\begin{array}{l}\text { membuat peraturan memiliki kekuatan hukum kuat } \\
\text { sehingga segala kegiatan berpacu pada peraturan daerah. }\end{array}$ \\
\hline memberikan dorongan \\
\hline memberikan penyuluhan \\
\hline memberikan pelatihan \\
\hline membantu mencari sumber pendanaan \\
\hline Kerjasama & mengajak masyarakat melakukan pemilahan \\
\hline Monitoring \& Evaluasi & memberikan informasi \\
\hline & menjalin hubungan kerjasama dengan mitra \\
\hline & mengawasi alur pendanaan \\
\hline Sumber : Hasil Analisis, 2018 & mengawasi pelaksanaan kegiatan \\
\hline
\end{tabular}

\subsection{Integrasi Konsep Arnstein Dengan Definisi Partisipasi Birokrat}

Jenjang partisipasi Arnstein pada birokrat dinilai atas tingkatan wewenang, perencanaan, pelaksanaan, pengelolaan keuangan, dan sebagainya yang telah dipercayakan kepada publik (masyarakat). Berikut pengertian dari setiap tingkat anak tangga partisipasi Arnstein, seperti yang dapat dilihat pada Tabel 4.

\section{Tabel 4.Integrasi Kunci Delapan Tangga Partisipasi}

\begin{tabular}{|c|c|c|c|}
\hline & Tingkat & Pengertian & Partisipasi \\
\hline 1 & Manipulation & $\begin{array}{l}\text { Birokrat memiliki kewenangan sepenuhnya dalam } \\
\text { mengatur suatu program mulai dari pendanaan, } \\
\text { perencanaan, pelaksanaan dan pengawasandan tanggung } \\
\text { jawab dengan tidak melibatkan masyarakat. }\end{array}$ & \multirow[t]{2}{*}{ Non Participation } \\
\hline 2 & Therapy & $\begin{array}{l}\text { Birokrat hanya memberikan informasi terkait terbentuknya } \\
\text { program, tanpa melibatkan masyarakat dalam rencana } \\
\text { pembuatan program }\end{array}$ & \\
\hline 3 & Informing & $\begin{array}{l}\text { Birokrat hanya memberikan informasi kepada masyarakat } \\
\text { mengenai hak dan tanggung jawab mereka dalam } \\
\text { menjalankan program, tanpa melibatkan masyarakat } \\
\text { dalam rencana pembuatan program. }\end{array}$ & \multirow{3}{*}{ Tokenism } \\
\hline 4 & Consultation & $\begin{array}{l}\text { Birokrat memperbolehkan masyarakat berpendapat, dan } \\
\text { dipersilahkan menyampaikan usulan mengenai suatu } \\
\text { program, walaupun tidak ada jaminan saran untuk } \\
\text { diterima. }\end{array}$ & \\
\hline 5 & Placation & $\begin{array}{l}\text { Birokrat memegang peranan paling tinggi dalam } \\
\text { menentukan alur pelaksanaan suatu program. bahkan, } \\
\text { struktur keanggotaan dalam suatu program dibentuk. }\end{array}$ & \\
\hline 6 & Partnership & $\begin{array}{l}\text { Birokrat berada dalam level yang } \\
\text { masyarakat, dimana tanggung jawab suatu } \\
\text { ditanggung oleh kedua pihak. }\end{array}$ & Citizen Power \\
\hline
\end{tabular}




\begin{tabular}{llll}
\hline & Tingkat & \multicolumn{1}{c}{ Pengertian } & Partisipasi \\
\hline 7 & $\begin{array}{l}\text { Delegated } \\
\text { power }\end{array}$ & $\begin{array}{l}\text { Pada level ini birokrat memberi kewenangan kepada } \\
\text { masyarakat dimulai dari tahap perencanaan program, } \\
\text { yang kemudian perencanaan program tersebut disetujui } \\
\text { oleh birokrat. }\end{array}$ \\
\hline 8 & Citizen & $\begin{array}{l}\text { Birokrat sepenuhnya memberikan kewenangan kepada } \\
\text { control }\end{array}$ & $\begin{array}{l}\text { masyarakat tetapimasih ikut campur dalam menjalankan } \\
\text { suatu program. masyarakat dapat menyusun sendiri } \\
\text { kelembagaan dalam program tersebut,seperti melakukan } \\
\text { kerjasama dengan melakukan perubahan suatu program. }\end{array}$ \\
\hline
\end{tabular}

Sumber : Hasil Analisis, 2017

Berdasarkan pengertian yang tertera pada Tabel 4, teori Arnstein ditunjukan bagi dua kelompok yaitu: masyarakat dan birokrat yang ikut serta dan terlibat dalam bentuk wewenang, kerjasama dan tanggung jawab untuk mencapai tujuan dalam suatu program. Pada konsep Arnstein, jika partisipasi masyarakat terdapat pada level 8 (citizen contro) maka dikatakan partisipasi masyarakat semakin tinggi karena masyarakat sepenuhnya menjalankan program. Berarti birokrat pun tinggi partisipasinya karena membiarkan masyarakat untuk menjalankan program dari awal hingga akhir serta sepenuhnya sudah membagi kewenangan kepada masyarakat. Sebagaiman tercantum pada PP 81 tahun 2012 yang menyatakan bawa pengurangan sampah diwujudkan dengan keterlibatan aktif masyarakatnya dalam program. Hal ini dapat diartikan bahwa masyarakat sebagai sumber sampah sadar bahwa mereka harus bisa mengelola buangan/limbahnya sendiri, tidak merugikan masyarakat/lingkungan sekitarnya. Sedangkan birokrat sangat diperlukan dalam pembuatan program, memperbaiki teknologi yang diterapkan, serta memberikan dukungan koordinasi di seluruh kota.

Dampak dari tingginya partisipasi langsung birokrat ialah masyarakat tidak akan berkembang serta tidak akan berpartisipasi dalam suatu program sedangkan tujuan diadakan program adalah untuk memberdayakan masyarakat bukan tergantung dari birokrat serta mengubah perilaku masyarakat menuju budaya hidup yang sehat. Partisipasi tersebut, menggambarkan bagaimana terjadinya pembagian kewenangan yang adil antara birokrat sebagai penyedia program dan masyarakat sebagai penerima program.Dalam penelitian ini, saya akan mengekstrak dari delapan tingkat partisipasi arnstein menjadi tiga jenis partisipasi yang masih menurut Arnstein, lihat pada Tabel 4.

\subsection{Perancangan Alat Ukur Untuk Wawancara}

Perancangan kuesioner dalam penelitian ini terbagi menjadi 3 (tiga) bagian yaitu:

Bagian I identitas responden, beberapa pertanyaan karakteristik yang bisa digunakan untuk mengklasifikasi responden diantaranya :
a. Jenis Kelamin
b. Pendidikan
c. Pekerjaan
d. Jabatan
e. Lama bekerja

Pertanyaan ini digunakan analisisnya untuk mengetahui latar belakang dari setiap responden mempengaruhi dari tingkat partisipasi birokrat, karna setiap birokrat memiliki kewenangan dan tanggung jawab yang berbeda.

Bagian II umum, pertanyaan ini menyediakan beberapa jawaban / arternatif dan responden hanya memilih satu di antaranya yang sesuai dengan pendapatnya. Pertanyaan pada bagian dua(umum) digunakan untuk mengetahui pengetahuan responden terkait program pengurangan sampah di Kota Bandung untuk Kawasan Bebas Sampah (KBS), Bank Sampah (BS), Biodigester (BD). Pertanyaan-pertanyaan yang diajukan dalam bagian dua yaitu:

a. Pengetahuan tentang program 
b. Peran serta aktif dalam program

c. Wilayah pelaksanaan program

d. Pengetahuan terhadap sistem monitoring dan evaluasi

Pertanyaan ini digunakan untuk menghubungan responden dengan program tersebut.

Bagian III khusus, pertanyaan pada bagian ini adalah bagian utama dalam penelitian karena akan diperoleh tingkat partisipasi birokrat dalam pengurangan sampah di Kota Bandung. Pertanyaan ini dibuat berdasarkan parameter yang telah diidentifikasi sebelumnya. Pertanyaan digunakan dalam wawancara untuk mencari informasi, meminta keterangan, atau menanyakan pendapat dari narasumber dengan cara tanya jawab. Jenis pertanyaan ini bersifat tertutup karena untuk tiap pertanyaan telah tersedia jawabannya berupa pilihan, tetapi setiap pertanyaan tersebut memiliki kunci jawaban yang menunjukan tingkat partisipasi berdasarkan Arnstein.Partisipasi birokrat dapat terukur karena peran serta birokrat dapat dibedakan pada setiap tingkatnya. Partisipasi birokrat dalam pengurangan sampah perlu dilakukan untuk mengetahui sejauh mana partisipasi birokrat terhadap partisipasi masyarakat. Selain itu, dengan adanya program yang diberikan birokrat untuk mengurangi fungsi kontrol birokratnya terhadap masyarakat dan di lain pihak meningkatkan kemandirian masyarakat dalam segala aspek kehidupan berbasis lingkungan hidup.

\subsection{Desain Sampel}

Penelitian ini akan dilakukan pada birokrat pemerintah, dan birokrat non pemerintah di Kota Bandung yang di fokuskan pada keterlibatan mereka dalam program KBS, BS dan BD. Hal tersebut dikarenakan peneliti ingin mengetahui tingkat partisipasi birokrat dalam pengurangan sampah pada program tersebut di Kota Bandung. Jumlah responden dalam penelitian ini dapat dilihat pada Tabel 5.

Tabel 5 Jumlah Responden

\begin{tabular}{|c|c|c|c|c|c|c|c|c|}
\hline Kelompok Birokrat & \multicolumn{2}{|c|}{ Pemerintah } & \multicolumn{5}{|c|}{ Non Pemerintah } & \multirow{2}{*}{ Total } \\
\hline Lembaga & DLHK & PD.K & $\mathrm{HL}$ & LPTT & YPBB & GSSI & Tokoh masyarakat & \\
\hline Populasi & 11 & 38 & 10 & 7 & 12 & 16 & 48 & 142 \\
\hline Jumlah & \multicolumn{2}{|c|}{49} & \multicolumn{4}{|c|}{45} & 48 & 142 \\
\hline$\%$ & 0.08 & 0.27 & 0.07 & 0.05 & 0.08 & 0.11 & 0.34 & 1.00 \\
\hline Responden & 1 & 10 & 1 & 1 & 1 & 2 & 16 & 32 \\
\hline
\end{tabular}

Sumber: Hasil Analisis, 2018

Penentuan responden didasarkan pada struktur organisasi di setiap birokrat yang terlibat secara langsung dalam ketiga program tersebut. Untuk DLHK hanya bidang kebersihan, dan untuk PDK hanya bidang operasional, yang sesuai dengan tugas pokok, fungsi, wewenang

dan yang bertanggung jawab terhadap pengelolaan sampah di Kota Bandung. Sementara untuk non pemerintah/LSM karena pada struktur organisasi semuanya bergerak dalam program pengurangan sampah, maka seluruh bidangnya menjadi responden, serta untuk masyarakat dicari tokoh-tokoh yang berperan aktif dalam program tersebut di lingkungan sekitar.

\subsection{Perencanaan Kunci Jawaban}

Perencanaan kunci jawaban menggunakan skoring dan ranking.Responden akan menjawab salah satu dari jawaban kuantitatif yang telah disediakan.Terdapat tiga kunci jawaban yaitu (i) tingkat citizen power yang bernilai 3 ketika birokrat hanya memberikan stimulus dalam program karena sudah memberikan kewenangan kepada masyarakat, (ii) tingkat tokenism yang bernilai 2 ketika birokrat sudah memberikan masyarakat untuk berpendapat dan berpartisipasi, (iii) tingkat non participation yang bernilai 1 ketika birokrat tidak melibatkan masyarakat. 
Pada jumlah pilihan pertanyaan mempunyai nilai jawaban 3 dengan jumlah pertanyaan yang diajukan terdapat 13 buah. Skor minimum mendapat nilai 1 sedangkan skor maxsimum mendapat nilai 3. Maka dapat diketahui setiap responden memiliki skor minimum13 dan skor maxsimum39. Karena rentang dari skor 13 ke 39 adalah sebesar 27, maka setelah dibagi dengan 3 level partisipasi, didapat rentang untuk masing-masing 9 angka. Bahwa setiap responden akan mempunyai skor tingkat partisipasi, skor tersebut dilihat pada Tabel 6.

\section{Tabel 6 Kriteria Penilaian}

\begin{tabular}{ccc}
\hline Tingkat Partisipasi & Nilai & Skor \\
\hline Citizen Power & 3 & $31-39$ \\
\hline Tokenism & 2 & $22-30$ \\
\hline Non Participation & 1 & $13-21$ \\
\hline
\end{tabular}

Sumber: Hasil Analisis, 2018

\section{KESIMPULAN}

Berdasarkan analisis dan pembahasan yang telah dilakukan, didapat hasil sebuah alat ukur yang dapat digunakan untuk mengukur tingkat partisipasi birokrat dalam pengelolaan sampah, yaitu berupa daftar pertanyaan. Daftar pertanyaan tersebut terdiri dari 3 bagian, yaitu identitas, umum, dan khusus. Alat ukur utama adalah di bagian khusus yang memiliki 13 pertanyaan yang sudah mencakup pertanyaan terkait tiga tahapan program dengan parameter sarana \& prasarana, aturan, kerjasama, pendampingan, dana, serta monitoring dan evaluasi. Rancangan daftar pertanyaan ini dibuat sehingga nilai partisipasi yang paling tinggi adalah 39, sedangkan nilai partisipasi yang paling rendah adalah 13.

\section{DAFTAR RUJUKAN}

Anonim. (2017). Kamus Besar Bahasa Indonesia Online. Kbbi.web.id. diakses pada tanggal 18 Agustus 2017, pukul 16.42 Wib. Bandung.

Asteria, Donna\&Heruman, H . (2016). Hubungan Tingkat Penerapan Prinsip Pengembangan Masyarakat Dengan Keberhasilan Program Csr, 02, 171-181.

Arnstein, Sherry R. (1995). A Ladder of Citizen Participation dalam Jay M. Stein (ed). Classic Reading in Urrban Planning : An Introduction. McGraw-Hill, Inc, New York.

Ayu Pratiwi, Finka. (2016). Studi Pengukuran Tingkat Partisipasi Masyarakat Terhadap Pengelolaan Sampah Di Kelurahan Sukaluyu. Tugas Akhir S-1, Jurusan Teknik Lingkungan, FTSP-Institut Teknologi Nasional. Bandung.

Badan Pengelola Lingkungan Hidup. (2014). Petunjuk Teknis Perwujudan Kawasan Bebas Sampah Kota Bandung. Bandung: BPLH.

Jalal, Fasli dan Dedi Supriadi. (2001).Reformasi Pendidikan Dalam Konteks Otonomi Daerah. Yogyakarta: Adicita Karya Nusa.

Nurviyasari, Fitri. (2012). Peran Tokoh Masyarakat Dalam Meningkatkan Partisipasi Warga Belajar Program Keaksaraan Fungsional Di Pkbm Tanjungsari, Tanjungharjo, Nanggulan, Kulon Progo. Yogyakarta: Universitas Negeri Yogyakarta.

Peraturan Walikota Bandung nomor 1390 tahun 2016 tentang kedudukan, susunan organisasi, tugas dan fungsi serta tata kerja Dinas Lingkungan Hidup dan Kebersihan Kota Bandung. Bandung: DLHK.

Peraturan Walikota Bandung Nomor 101 Tahun 2006 tentang susunan organisasi dan tata kerja Perusahaan Daerah Kebersihan Kota Bandung. Bandung: PD.Kebersihan

Republik Indonesia. 2008. Undang-Undang Nomor 18 Tahun 2008 tentang Pengelolaan Sampah. Kepala Biro Hukum dan Humas. Jakarta 
Republik Indonesia. 2012. Peraturan Pemerintah Nomor 81 Tahun 2012 tentang Pengelolaan Sampah Rumah Tangga dan SampahSejenis Rumah Tangga . Kepala Biro Hukum dan Humas. Jakarta

Sedarmayanti. (2009). Sumber Daya Manusia dan Produktivitas Kerja. Bandung: CV Mandar Maju.

Soleh A.Z. (2005). IImu Statistik Pendekatan Teoritis dan Aplikatif Disertai contoh Penggunaan SPSS. Rekayasa Sains. Bandung.

Sugiyah. (2001).KlasifikasiPartisipasi.http://Sacafirmansyah.wordpress.com/. diakses pada9 Mei 2017.

Sundariningrum. (2001). Klasifikasi Partisipasi.Jakarta: Grasindo

Sumaryadi, I Nyoman. (2010). Perencanaan Pembangunan Daerah Otonom dan Pemberdayaan Masyarakat. Jakarta: Penerbit Citra Utama 